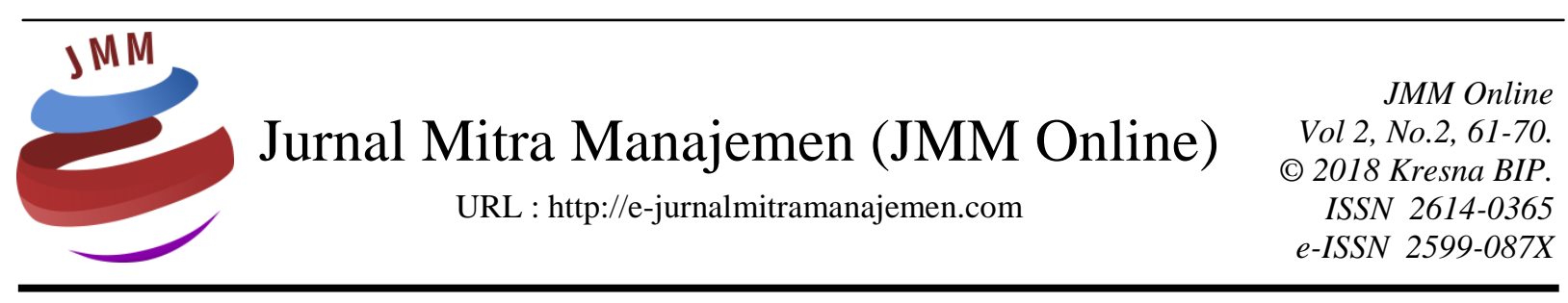

\title{
MANAJEMEN PERUBAHAN DALAM REFORMASI BIROKRASI MENUJU INFORMATION TECHNOLOGY (IT)
}

\author{
Dr. Yusriadi, S.H., M.Si. \\ Sekolah Tinggi Ilmu Hukum Pengayoman
}

INFORMASI ARTIKEL

Dikirim : 25 Februari 2018

Revisi pertama : 26 Februari 2018

Diterima : 02 Maret 2018

Tersedia online : 13 April 2018

Kata Kunci : Manajemen, Reformasi Birokrasi, Pelayanan Publik

Email : yusriadi.yusriadi@uqconnect.edu.au

\section{ABSTRAK}

Pelaksanaan reformasi birokrasi telah mendapatkan landasan hukum melalui penerbitan Peraturan Presiden Nomor 81 Tahun 2010 tentang Grand Design Reformasi Birokrasi 2010-2025. Salah satu agenda Indonesia pada reformasi birokrasi adalah menciptakan Good Governance di Indonesia. Pada hakikatnya merupakan upaya untuk melakukan pembaharuan dan perubahan mendasar terhadap sistem penyelenggaraan pemerintahan terutama menyangkut aspekspek kelembagaan (organisasi), ketatalaksanaan (business rosess) dan sumber daya manusia aparatur.

Perubahan pengelolaan sektor publik tidak hanya bertujuan memodernisasi institusi negara dan mengurangi biaya pelayanan publik, namun juga diharapkan untuk menghasilkan kerjasama yang dinamis antara pemerintah dengan masyarakat sipil dan sektor swasta. Salah satu usaha pembaharuan untuk menunjang reformasi birokrasi adalah menggunakan teknologi informasi. Usaha ini dinilai efektif untuk memperbaiki birokrasi di Indonesia. Information Technology didefinisikan sebagai penyampaian layanan dan informasi dari pemerintah kepada publik menggunakan sarana elektronik yang mempermudah masyarakat berkomunikasi dengan pemerintah dan ikut berpartisipasi dalam proses pembuatan keputusan, mengekspresikan kebutuhan nyata masyarakat.

Tulisan ini mendeskripsikan manajemen perubahan dalam reformasi birokrasi dengan penggunaan teknologi informasi dan komunikasi untuk pengembangan sistem informasi yang berdampak tercapainya efisiensi dan efektivitas manajemen pemerintah daerah. 


\section{PENDAHULUAN \\ Latar Belakang}

Birokrasi Indonesia selalu menjadi sebuah opini publik yang tidak pernah membosankan. Hal ini disebabkan karena hingga kini birokrasi di Indonesia masih problematik. Birokrasi yang kurang ideal menjadi salah satu masalah di Indonesia, keluhan terhadap rendahnya kinerja pelayanan publik dan minimnya kualitas sumberdaya aparatur seperti tidak pernah ada akhirnya dan belum dapat ditemukan solusi efektif untuk mengatasinya, seperti kolusi, korupsi dan nepotisme sampai dengan sistem birokrasi yang buruk menjadi hambatan dalam mewujudkan birokrasi yang pro terhadap kepentingan rakyat, hal ini melahirkan patologi dalam birokrasi.

Reformasi birokrasi merupakan salah satu syarat fundamental dalam perbaikan pelayanan kepada masyarakat dan perbaikan perekonomian bangsa secara menyeluruh. Dalam kenyataannya, reformasi tidak semudah membalikan telapak tangan tanpa kerja keras semua komponen bangsa termasuk para birokrat itu sendiri. Kondisi birokrasi Indonesia di era reformasi saat ini bisa dikatakan belum menunjukkan arah perkembangan yang baik, karena masih banyak ditemukan birokrat yang menganggap rakyat yang membutuhkannya, praktik KKN yang masih banyak terjadi dan mentalitas birokrat yang masih jauh dari harapan. Untuk melaksanakan fungsi birokrasi secara tepat, cepat dan konsisten untuk mewujudkan birokrasi yang akuntabel dan baik, maka Pemerintah merumuskan sebuah peraturan untuk menjadi landasan dalam pelaksanaan reformasi birokrasi di Indonesia, yaitu Peraturan Presiden Nomor 80 Tahun 2011 tentang Grand Design reformasi birokrasi Indonesia 2010-2025.

Berbagai jenis atau bentuk hambatan reformasi birokrasi yang sudah sangat dikenal dan dirasakan masyarakat, antara lain ketika setiap mengurus sesuatu di kantor pemerintah merasakan prosedur yang berbelit-belit, lamban atau membutuhkan waktu yang lama, membutuhkan biaya yang besar termasuk biaya-biaya tambahan, pelayanan yang kurang ramah, terjadinya praktek kolusi, korupsi dan nepotisme, dan lain-lain. Menghadapi berbagai hambatan reformasi birokrasi tersebut menyebabkan kinerja birokrasi sampai dewasa ini belum menunjukkan perubahan yang signifikan (Yusriadi, 2017: 99-108 dalam Jurnal Ilmiah Ilmu Administrasi Publik).

Salah satu usaha pembaharuan untuk menunjang reformasi birokrasi adalah menggunakan information technology. Usaha ini dinilai efektif untuk memperbaiki birokasi di Indonesia. Information technology dapat diterapkan di lembaga negara seperti lembagai legislatif, eksekutif dan yudikatif. Bahkan pejabat administrasi publik pun dapat menggunakan teknologi dalam menyampaikan berbagai informasi mengenai pemerintahan kepada masyarakat. Dengan information technology kerja pemerintahan dinilai dapat lebih efiseien. Masyarakat juga dapat mengontrol langsung kinerja pada pejabat publik, ini tentunya akan membawa pengaruh yang baik dalam birokrasi di Indonesia.

Di Indonesia teknologi informasi telah diadopsi sejak tahun 2001 melalui Instruksi Presiden Nomor 6 Tahun 2001 tentang Telematika (Telekomunikasi, Media dan Informatika) bahwa aparat pemerintah harus menggunakan teknologi telematika untuk mendukung good governance dan mempercepat proses demokrasi. Hal ini bersesuaian dengan prinsip paradigma baru new public manajemen dan new public service yang mengedepankan kualitas dan mutu pelayanan Pemerintah kepada 
masyarakat. Penegasan tentang urgensi teknologi informasi juga didukung dengan Instruksi Presiden Nomor 3 Tahun 2003 tentang Kebijakan dan Strategi Nasional Pengembangan e-Government serta Peraturan Menteri Komunikasi dan Informatika Nomor 126/M/KI/K/VI/2002 perihal Edaran Pendayagunaan Situs sebagai bentuk keseriusan pemerintah memanfaatkan teknologi informasi dan komunikasi di dalam proses pemerintahan.

Implementasi teknologi informasi pada dasarnya dapat memberikan peluang yang sangat besar bagi pengembangan daerah. Dimana daerah dapat menggunakan fasilitas yang ada untuk mempermudah proses layanan, memperkenalkan potensi organisasi, meningkatkan interaksi dengan masyarakat dan bisnis. Proses mengimplementasi teknologi informasi tidaklah mudah, tidak hanya dengan memasang komputer sudah disebut teknologi informasi. Ada banyak perencanaan dan proses yang perlu dilakukan. Banyak kejadian implementasi teknologi informasi khususnya di Indonesia mengalami kegagalan. Hambatan teknologi informasi tidak hanya dihadapi oleh Pemerintah Indonesia (atau pemerintah daerah) saja. Di negara lain pun khususnya Negara berkembang, hal tersebut masih menjadi masalah. Hambatan ini harus diperhatikan dalam perencanaan implementasi teknologi informasi.

Langkanya sumber daya manusia (SDM) yang handal, teknologi informasi merupakan sebuah bidang yang baru, dimana Pemerintah umumnya jarang memiliki SDM yang handal di bidang teknologi informasi. SDM yang handal ini biasanya ada di lingkungan bisnis. Kekurangan SDM ini menjadi salah satu penghambat dalam implementasinya. Hal yang juga menghambat dalam pelaksanaan perubahan adalah infrastruktur yang belum memadai dan mahal. Infrastruktur telekomunikasi Indonesia belum tersebar secara merata. Di berbagai daerah di Indonesia masih belum tersedia saluran telepon, atau bahkan aliran listrik. Masalah akses yang terbatas, tempat akses informasi jumlahnya juga masih terbatas, di beberapa tempat di luar negeri, pemerintah dan masyarakat bergotong royong untuk menciptakan access point yang terjangkau, seperti di perpustakaan umum (public library). Sedangkan di Indonesia hal ini dapat dilakukan di kantor pos, kantor pemerintahan, dan tempat-tempat umum lainnya.

Untuk memaksimalkan manfaat teknologi informasi, maka diperlukan proses kontrol yang memadai pada lifecycle e-government untuk memastikan kalau sistem yang diterapkan sesuai dengan kebutuhan, investasi yang dikeluarkan dapat dipertanggungjawabkan, operasinya baik dan dapat mendukung pencapaian tujuan daerah. Untuk inilah pembahasan manajemen perubahan reformasi birokrasi terhadap penggunaan teknologi informasi menjadi sesuatu hal yang menarik untuk dibahas, sebagai bentuk terobosan dalam inovasi birokrasi terhadap bentuk reformasi dalam pelayanan publik.

\section{PEMBAHASAN}

Pemerintahan di seluruh dunia membangun institusinya untuk mencapai tujuan dan sasaran yang ditetapkan. Proses pembangunan institusi tersebut dikenal sebagai administrasi pembangunan (development administration) yang merupakan bagian administrasi publik. Pada era teknologi informasi dewasa ini, perubahan pengelolaan administrasi publik mendapat tantangan untuk terus beradaptasi yang diakibatkan 
fenomena globalisasi. Situasi ini mendorong pemerintahan untuk meningkatkan kemampuannya dalam memberikan pelayanan publik yang responsif secara terus menerus, melalui pengelolaan strategik kebijakan sektor publik yang inovatif.

Perubahan administrasi publik telah menyita perhatian kajian para pakar sejak dekade 1970. Leemans (1976) mengidentifikasi enam alasan utama yang mendorong perubahan tersebut, yaitu: 1) perlunya membangun fundamental pemerintahan agar terjadi integrasi nasional di negara-negara yang relatif baru merdeka; 2) munculnya tuntutan agenda politik baru agar masyarakat dapat menikmati tingkat kehidupan lebih baik; 3) adanya proses institusionalisasi lembaga politik; 4) munculnya fenomena profesionalisasi, spesialisasi, dan diferensiasi; 5) adanya tuntutan peluasan pelayanan pemerintah dari tingkat lokal ke level nasional dan regional; 6) munculnya nilai dan sikap baru (misalnya demokratisasi, partisipasi, dan konfrontasi).

Perubahan pengelolaan sektor publik tidak hanya bertujuan memodernisasi institusi negara dan mengurangi biaya pelayanan publik, namun juga diharapkan untuk menghasilkan kerjasama yang dinamis antara pemerintah dengan masyarakat sipil dan sektor swasta, berkaitan dengan peningkatan kualitas pelayanan publik, peningkatan tanggung jawab sosial, dan menjamin partisipasi warga negara lebih luas dalam proses pengambilan keputusan dan pemberian umpan balik terhadap kinerja sektor publik (Penger and Tekavcic , 2008).

Reformasi birokrasi dilaksanakan untuk memperbaiki tujuan administrasi publik yang ingin dicapai. Tanpa tujuan pemerintah yang jelas, tidak akan terjadi reformasi birokrasi. Lee lebih jauh membedakan tujuan pelaksanaan reformasi birokrasi berbeda-beda untuk tiap negara yang memiliki tingkat perkembangan sosial budaya yang berbeda, yaitu negara yang masyarakatnya sedang berkembang, negara dengan masyarakat tradisional dan negara yang masyarakatnya telah maju. Tugas administrator sebagai pelaksana administrasi di negara yang masyarakatnya sedang berkembang (developing society), berbeda dengan tugas administrator di negara yang masyarakat yang sudah maju atau masyarakat tradisional. Di negara yang masyarakatnya masih tradisional, administrator bertugas sebagai pelayan raja (royal servant) atau agen negara kolonial, di negara yang masyarakatnya maju sebagai regulator untuk menjamin tersedianya kepentingan publik dari kelompok kepentingan lainnya, sedangkan di negara yang masyarakatnya sedang berkembang administrator berperan sebagai agen perubahan.

Faktor penting dalam melaksanakan reformasi birokrasi adalah adanya inovasi dan kemampuan menghasilkan kemakmuran (wealth creation). Hal tersebut tercapai melalui sejumlah ide dan aktor baru didalam kombinasi tugas dan hubungan dalam proses administrasi dan kebijakan. Target yang ingin dicapai melalui program ini antara lain adalah meningkatnya efisiensi dan efektivitas proses manajemen pemerintahan serta kinerja di Kementerian/Lembaga dan Pemerintah Daerah. Tujuan penggunaan teknologi informasi adalah mewujudkan tatalaksana yang ringkas, efektif, efisien dan transparan serta memberi pelayanan prima. Kebijakan teknologi informasi diarahkan pada perubahan sistem manajemen dengan konsep manajemen modern agar cepat, akurat, pendek jaraknya dan pemanfaatan teknologi modern di lingkungan instansi pemerintah. 
Information technology di Indonesia mulai sejak tahun 2001 dengan lahirnya Instruksi Presiden No. 6 Tahun 2001 tanggal 24 April 2001 tentang Telematika (Telekomunikasi, Media dan Informatika) yang menyatakan bahwa aparat pemerintah harus menggunakan teknologi telematika untuk mendukung good governance dan mempercepat proses demokrasi. Namun dalam perjalanannya, inisiatif pemerintah pusat ini tidak mendapat dukungan serta respon dari segenap pemangku kepentingan pemerintah dengan ditandai pemanfaatan teknologi informasi tidak berjalan dengan baik.

Berdasarkan data yang ada, pelaksanaan teknologi informasi di Indonesia sebagian besar baru pada tahap publikasi situs oleh pemerintah atau baru pada tahap pemberian informasi. Data Maret 2002 menunjukkan 369 kantor pemerintahan telah membuka situs mereka. Akan tetapi $24 \%$ dari situs tersebut gagal untuk mempertahankan kelangsungan waktu operasi karena anggaran yang terbatas. Saat ini hanya 85 situs yang beroperasi dengan pilihan yang lengkap. (Jakarta Post, 15 Januari 2003). Indikator lainnya adalah persentasi internet baru mencapai 1,9 juta penduduk atau 7,6 persen dari total populasi Indonesia pada tahun 2001. Pada tahun 2002 dengan 667.000 jumlah pelanggan internet dan 4.500.000 pengguna komputer dan telepon, persentasi penggunaan internet di Indonesia sangatlah rendah. (Sumber: Asosiasi Penyelenggara Jasa Internet Indonesia/APJII).

Pada tahun 2003, di era Presiden Megawati Soekarno Putri, Pemerintah mengeluarkan suatu kebijakan yang lebih fokus terhadap pelaksanaan informasi teknologi, melalui Instruksi Presiden yaitu Inpres Nomor 3 tahun 2003. Inpres ini berisi tentang Strategi Pengembangan informasi teknologi yang juga sudah dilengkapi dengan berbagai Panduan tentang informasi teknologi seperti: Panduan Pembangunan Infrastruktur Portal Pemerintah; Panduan Manajemen Sistem Dokumen Elektronik Pemerintah; Pedoman tentang Penyelenggaraan Situs Web Pemda; dan lain-lain. Demikian pula berbagai panduan telah dihasilkan oleh Depkominfo pada tahun 2004 yang pada dasarnya telah menjadi acuan bagi penyelenggaraan informasi teknologi di pusat dan daerah. Dalam Inpres ini, Presiden dengan tegas memerintahkan kepada seluruh Menteri, Gubernur, Walikota dan Bupati untuk membangun electronic goverment dengan berkoordinasi dengan Menteri Komunikasi \& Informasi.

Dilihat dari pelaksanaan aplikasi informasi teknologi setelah keluarnya Inpres ini maka dapat dikatakan bahwa perkembangan pelaksanaan implementasi ini masih jauh dari harapan. Data dari Depkominfo (2005) menunjukkan bahwa hingga akhir tahun 2005 lalu Indonesia baru memiliki:

564 domain go.id;

295 website pemerintah pusat dan pemda;

226 website telah mulai memberikan layanan publik melalui website 198 website pemda masih dikelola secara aktif.

Beberapa pemerintah daerah memperlihatkan kemajuan cukup berarti. Bahkan Pemkot Surabaya sudah mulai memanfaatkan informasi teknologi untuk proses pengadaan barang dan jasa (e-procurement). Beberapa pemda lain juga berprestasi baik dalam pelaksanaannya seperti: Pemprov DKI Jakarta, Pemprov DI Yogyakarta, Pemprov Jawa Timur, Pemprov Sulawesi Utara, Pemkot Yogyakarta, Pemkot Bogor, 
Pemkot Tarakan, Pemkab Kebumen, Pemkab. Kutai Timur, Pemkab. Kutai Kartanegara, Pemkab Bantul, Pemkab Malang.

Sementara itu dari sisi infrastruktur, layanan telepon tetap masih dibawah 8 juta satuan sambungan dan jumlah warung telekomunikasi (Wartel) dan warung Internet (Warnet) yang terus menurun karena tidak sehatnya persaingan bisnis. Telepon seluler menurut data Depkominfo tersebut telah mencapai 24 juta ss. Meski kepadatan telepon tetap di beberapa kota besar bisa mencapai 11\%-25\%, kepadatan telepon di beberapa wilayah yang relatif tertinggal baru mencapai $0,2 \%$. Jangkauan pelayanan telekomunikasi dalam bentuk akses telepon baru mencapai $65 \%$ desa dari total sekitar 67.800 desa yang ada di seluruh tanah air. Jumlah telepon umum yang tersedia hingga saat ini masih jauh dari target 3\% dari total sambungan seperti ditargetkan dalam penyusunan Program Pembangunan Jangka Panjang II dahulu.

Sementara itu jumlah pelanggan dan pengguna Internet masih tergolong rendah jika dibandingkan dengan total penduduk Indonesia. Hingga akhir 2004 berbagai data yang dikompilasi Asosiasi Penyedia Jasa Internet Indonesia (APJII) memberikan jumlah pelanggan Internet masih pada kisaran 1,9 juta, sementara pengguna baru berjumlah 9 juta orang. Rendahnya penetrasi Internet ini jelas bukan suatu kondisi yang baik untuk mengurangi lebarnya kesenjangan digital (digital divide) yang telah disepakati pemerintah Indonesia dalam berbagai pertemuan Internasional untuk dikurangi.

Salah satu kendala utama dalam pelaksanaan informasi teknologi adalah kurangnya ketersediaan infrastruktur telekomunikasi. Jaringan telepon masih belum tersedia di berbagai tempat di Indonesia. Biaya penggunaan jasa telekomunikasi juga masih mahal. Harapan kita bersama hal ini dapat diatasi sejalan dengan perkembangan telekomunikasi yang semakin canggih dan semakin murah. Kendala lainnya adalah masih banyaknya penyelenggara pelayanan publik baik di pusat maupun daerah yang belum mengakomodir layanan publiknya dengan fasilitas internet. Terutama pada institusi pusat dengan unit pelaksana teknisnya dan juga dengan institusi lain dengan item pelayanan yang sama $(\mathrm{G} 2 \mathrm{G}=$ Government to Government $)$. Dengan kata lain, hal ini belum terkoordinir dengan baik dan masih kuatnya kepentingan masing-masing sektor.

Tujuan utama pelayanan dengan penggunaan teknologi informasi adalah untuk memenuhi kebutuhan dan tuntutan stakeholders. Jika pelayanan sistem IT yang diberikan oleh pemerintah benar-benar untuk kepentingan warga negara maka masuk akal jika pemerintah perlu mencari tahu apa keinginan dan harapan warga negara mengenai pelayanan dengan sistem IT (Mundy \& Musa, 2010, p. 147). Hal yang mendasar dalam pelaksanaan penggunaan IT dalam suatu pelayanan, yaitu :

\section{Kesiapan Organisasi}

Kesiapan organisasi meliputi : sikap dan perbuatan dari orang-orang di dalam organisasi tersebut dan ketersediaan mesin terhadap lingkungan kerja elektronik (Yonazi, Sol, \& Boonstra, 2010, p. 179). Salah satu hal yang harus dilakukan dalam manajemen perubahan dengan penerapan IT dalam suatu pelayanan adalah adanya kesiapan organisasi dalam menerima perubahan tersebut, artinya bahwa organisasi harus mempersiapkan diri dengan baik terhadap perubahan yang dilakukan dengan 
penggunaan teknologi modern dalam proses pelayanan publik, diharapkan organisasi mampu menyediakan suatu lingkungan kerja dimana didalam lingkungan tersebut beradaptasi dengan elektronik.

\section{Kesiapan Masyarakat}

Kesiapan warga negara ditentukan oleh keterampilan TIK, kemampuan keuangan, kepedulian akan keberadaan pelayanan TIK, pilihan akan komunikasi face to face, dan usia pengguna (Yonazi, Sol, \& Boonstra, 2010, p. 179). Salah satu hal yang juga terkait dalam manajemen perubahan dalam penggunaan IT adalah adanya kesiapan masyarakat untuk menggunakan teknologi modern dan hal ini tidaklah mudah dapat terlaksana dengan baik, mengingat Indonesia sebagai negara berkembang dengan sistem masyarakat yang heterogenic. Hal ini menjadi salah satu penghambat dalam manajemen perubahan menuju information technology. Sebagai salah satu contoh di desa sistem jaringan internet sangat jauh berbeda dengan sistem jaringan internet yang ada di perkotaan sehingga hal ini turut andil dalam pelaksanaan perubahan tersebut, di satu sisi masih banyak masyarakat yang belum memahami bagaimana sistem pelayanan berbasis online.

\section{Isu Pelayanan Instrinsik}

Masalah pelayanan umum termasuk didalamnya respon tepat waktu, manfaat, dan kenyamanan penggunaan pelayanan e-government (Yonazi, Sol, \& Boonstra, 2010, p. 180). Hal yang menjadi utama dalam manajemen perubahan dengan penerapan IT adalah adanya transparansi dalam pelayanan publik dengan syarat yang jelas dan adanya kepastian waktu yang jelas, sehingga diharapkan dengan penerapan IT ini dapat menciptakan akuntabilitas dalam suatu pelayanan publik. Hal ini juga dapat menhingdari terjadinya penggunaan calo oleh masyarakat, karena adanya kemudahan akses dalam proses pelayanan. Dalam Penjelasan Undang Undang Nomor 5 Tahun 2009 tentang Pelayanan Publik, khususnya Pasal 4 huruf h memberikan batasan tentang prinsip keterbukaan dalam pelayanan publik, antara lain dijelaskan bahwa setiap penerima pelayanan dapat dengan mudah mengakses dan memperoleh informasi mengenai pelayanan yang diinginkan.

\section{Akses}

Ketersediaan peralatan TIK menjelaskan ketersediaan peralatan terutama komputer untuk mengakses e-government (Yonazi, Sol, \& Boonstra, 2010, p. 181). Jika segala aspek penyelenggaraan pelayanan, khususnya yang berkaitan dengan hak dan kewajiban antara pemberi/penyelenggara layanan dengan pengguna layanan dapat diakses dengan mudah dan dipublikasikan secara terbuka sehingga mudah dipahami oleh publik, maka praktik penyelenggaraan tersebut memiliki tingkat keterbukaan yang tinggi, seperti : persyaratan, waktu, biaya, alur pelayanan, mekanisme pengaduan dan sebagainya. Sebaliknya, manakala semua atau sebagian dari aspek pelayanan tidak terbuka dan sulit untuk di akses oleh para pengguna layanan maupun para stakeholders, maka penyelenggaraan pelayanan tersebut memiliki tingkat keterbukaan yang rendah, atau dengan kata lain tidak memenuhi kaidah keterbukaan. 
Pencapaian information technology tidak dapat dilakukan secara instan. Perlu proses dan waktu yang panjang untuk mewujudkan, diperlukan strategi untuk mencapai tujuan pelaksanaan IT secara efektif dan efisien. Strategi pengembangan tersebut dimulai dari proses pemilihan bupati/walikota. Masyarakat diharapkan memilih seorang bupati/walikota yang visioner. Seorang bupati/walikota yang visioner mampu melihat jauh ke depan. Dengan demikian maka bupati/walikota ini berorientasi pada peningkatan kualitas pelayanan kepada masyarakat. Selain visioner, masyarakat hendaknya juga bupati/walikota yang mampu berpikir luar biasa. Hal ini sangat diperlukan untuk menembus sekat-sekat birokrasi yang selama ini berada dalam zona aman (comfort zone). Bupati/walikota seperti ini tidak hanya mengikuti aturan formal, namun juga mampu berinovasi untuk meningkatkan kualitas pelayanan kepada masyarakat. Perlu dibuat jembatan untuk mewujudkan pelaksanaan IT yang dipikirkan oleh bupati/walikota. Dalam hal ini jembatan tersebut berupa adanya pejabat dan aparat publik yang menguasai IT, peraturan daerah (perda) tentang pelaksanaan IT, dan APBD yang memuat anggaran dan kegiatan pengembangan IT. Pejabat dan aparat publik yang menguasai IT sangat diperlukan untuk menjabarkan visi dan misi bupati/walikota. Selain diperlukan penguasaan terhadap konsep teknologi informasi, juga diperlukan penguasaan terhadap teknik aplikasi teknologi informasi. Dengan didukung oleh pejabat dan aparat publik yang mumpuni, maka diharapkan implementasi teknologi informasi diharapkan memberikan manfaat yang besar bagi masyarakat. Perda tentang teknologi informasi diperlukan untuk dijadikan sebagai panduan dan grand design dalam pengembangan teknologi informasi. Semua kegiatan teknologi informasi diharapkan mengacu pada perda untuk kesamaan langkah dalam rangka integrasi sistem aplikasi. Karena didalam hal ini ada beberapa aplikasi yang bekerja, maka kesamaan bahasa program menjadi sangat penting.

Dalam hal implementasi penggunaan teknologi informasi, maka diperlukan peran serta dari semua stakeholders, baik pemerintah, swasta, masyarakat, LSM, dan akademisi. Pemerintah mempunyai tugas yang jelas, yaitu sebagai penyelenggara teknologi informasi. Tugas swasta juga tidak kalah pentingnya. Sebagai contoh perusahaan telekomunikasi mengemban tugas bagaimana memberi dukungan untuk mengimplementasikan teknologi informasi ini dengan memberikan kemudahan akses internet bagi masyarakat. Paket data yang murah tentu menjadi pilihan utama bagi masyarakat. Selain itu peran swasta untuk memberikan informasi tentang lowongan pekerjaan juga sangat membantu masyarakat agar mudah melihat peluang kerja. Hanya dengan membuka website pemda, masyarakat sudah dapat melihat lowongan kerja tanpa perlu pergi ke kantor pos, membeli koran maupun mendatangi perusahaan tersebut. Peran LSM adalah memberikan pendampingan kepada masyarakat dengan memberdayakan masyarakat untuk turut berpartisipasi secara aktif dalam penggunaan teknologi informasi. Sedangkan peran akademisi adalah memberikan pelatihan kepada masyarakat untuk meningkatkan informasi. Dengan dukungan dari semua stakeholders ini maka diharapkan tujuan penerapan teknologi informasi dapat tercapai. 


\section{KESIMPULAN DAN SARAN \\ Kesimpulan}

Tujuan utama information technology mengarah pada sistem penyampaian pelayanan yang terhubung ke publik (konektivitas) secara lebih baik dan sistem berfungsi dengan baik (efisiensi). Tujuan konektivitas dicapai ketika ada penghematan biaya dalam investasi infrastruktur, output TIK menghasilkan pertumbuhan industri dan memberikan kesempatan yang lebih baik kepada masyarakat. Di sisi lain, efisiensi dicapai bila ada penghematan biaya keseluruhan, optimalisasi pendapatan pemerintah dan pencapaian efisiensi organisasi. Kohesi sosial-ekonomi didorong oleh keinginan pemerintah untuk mencapai efektivitas melalui pelayanan yang lebih baik dan peluang untuk warganya.

\section{Saran}

Ketika masuk dalam ranah implementasi teknologi informasi, maka diperlukan peran serta dari semua stakeholders, baik pemerintah, swasta, masyarakat, LSM, dan akademisi. Pemerintah mempunyai tugas yang jelas, yaitu sebagai penyelenggara informasi teknologi. Tugas swasta juga tidak kalah pentingnya.

\section{DAFTAR PUSTAKA}

Adebimpe A. Adenugba, Ojuge O. Folorunsho. 2012. Intl Journal; Bureaucratic Bottlenecks and Organizational Behavior Amongst Local Government Employees In Ibadan. Oyo State. Nigeria.

Afifudin \& Zein. 2011. Perencanaan Pembelajaran. Bandung: Universitas Islam Negri Gunung Djati.

Dwiyanto. 2011. Mengembalikan Kepercayaan Publik Melalui Reformasi Birokrasi. Jakarta. Gramedia Pustaka Utama.

Meymaharani R., Laily D., 2014, Perancangan E-Commerce Goody Bag Spunbod Menggunakan QR Code Berbasis Web Responsif. Prosiding Snatif, Teknik Infrmatika S1, Universitas Muria Kudus

Miles, Mathew \& Huberman A.Michael. 2014. Analisis Data KualitatifI. Jakarta. UI Press

Parica, Roni dkk. 2013. Pengaruh Laba Bersih, Arus Kas Operasi, Likuiditas, dan Profitabilitas terhadap Kebijakan Dividen Pada Perusahaan Automotive and Allied Product yang terdaftar di BEI. Jurnal Akuntansi Universitas Riau Vol.2 No.1. 2013

Rabah dan Abdallah, 2012. Decolorization of Acacia Seyal Gum Arabic. Annual Conference of Postgraduate Studies and Scientific Research Hall, Khartoum. Republic of Sudan. Rabah dan Abdallah, 2012. Decolorization of Acacia Seyal Gum Arabic. Annual Conference of Postgraduate Studies and Scientific Research Hall, Khartoum. Republic of Sudan.

Thoha, Miftah. 2011. Birokrasi Pemerintah Indonesia di Era Reformasi. Jakarta: Kencana Prenada Media Group.

Trochidis, Ilias. (2008). One-Stop Government: A Literature Review, www.onestopgovproject.org, http://www.fub.it/files/onestop gov literature review.pdf. 
Yonazi, J., Sol, H., \& Boonstra, A. 2010. Exploring Issues Underlying Citizen Adoption of eGovernment Initiatives in Developing Countries: The Case of Tanzania. Electronic Journal of e-Government , 8 (2), 176-188.

Yusradi \& Misnawati. 2017. Reformasi Birokrasi dalam Pelayanan Publik (Studi Pelayanan Terpadu Satu Pintu). Jurnal Ilmiah Ilmu Administrasi Publik. Volume 7 Nomor 2 Juli - Desember 2017. Hal 99-108 p-ISSN: 2086-6364, e-ISSN: 2549-7499 Homepage: http://ojs.unm.ac.id/index.php/iap/index

Yusriadi, Akib, and Ihsan. 2017. Bureaucratic Reform in Public Service: A Case Study on the Stop-Integrated Services. Mediterranean Journal of Social Sciences Vol 8 No 2 March. Page 253-258. 